\title{
The new frontier of consumer experiences: escape through pain
}

\author{
Bernard Cova ${ }^{1}$
}

Received: 21 February 2020 / Accepted: 29 April 2020 / Published online: 2 June 2020

(C) Academy of Marketing Science 2020

\begin{abstract}
Terms such as consumer experience and experiential consumption have become ubiquitous in the realm of marketing. The last decades have seen a dramatic increase in academic publications exploring these concepts across many different streams and have resulted in significant advances in scholarly understanding. Consumer culture theory (CCT) scholars have particularly participated in this effort by investigating extraordinary experiences and framing them as escapes from everyday life. This paper proposes a summary of CCT contributions on extraordinary experiences and emphasizes the way these works have used the structural/anti-structural coexistence theory to depict the experiences consumers live through. Then it mobilizes a fiction to improve the understanding of escape. This paper highlights how painful leisure pursuits enable consumers to reconnect with their bodies, affording them moments of escape from an otherwise saturated self. The paper shows how the concept of self-escape is important to envision the possibilities in marketing painful experiences.
\end{abstract}

Keywords Anti-structure $\cdot$ CCT $\cdot$ Escape $\cdot$ Experience $\cdot$ Orwell $\cdot$ Pain $\cdot$ Whitening

\section{Introduction}

Consumer experience is a key marketing concept that has enjoyed remarkable attention from consumer culture theory (CCT) scholars. Although no common understanding exists in marketing regarding what consumer experience entails, papers published under the broad umbrella of CCT tend to cohere with the notion of "extraordinary experience." A consumer experience is thus comprehended as an escape from daily routine. The burden of scripted life plans means consumers expand significant resources in trying to escape them. They offset the mundane and/or unsatisfactory nature of their existence with ephemeral escapes. Through a large variety of ethnographic investigations, CCT research has elaborated a conceptualization of these ephemeral escapes based on the structural/anti-structural dichotomy introduced by Victor Turner (1969). This has provided marketers with the major anti-structural dimensions to be implemented to produce a favorable experiential context in which the consumers can escape the structure of everyday life. However, changes in

Bernard Cova

bernard.cova@kedgebs.com

1 Marketing Department, Kedge Business School, BP 921 13288 Marseille Cedex 9, France society since the 2010s have paved the way for bringing consumer escapes to the next level: self-escape.

Through the analysis of a novel-Burning down George Orwell's House by Andrew Ervin (2015) - this paper reflects on a type of escape from our post-Orwellian world. The answer is pain! Through pain, consumers experience an absence from themselves that lightens the load of the "saturated self," an image introduced by Gergen (1991) by which he means a self that is continuously bombarded by social stimuli and thus in continuous construction or reconstruction. CCT scholars have investigated the recent appeal of intense physical and painful self-inflicted experiences, such as obstacle racing (Scott et al. 2017), pilgrimages and long trails (Husemann and Eckhardt 2019), and tattooing (Roux and Belk 2019). This new breed of experiences pushes the body to its limits and destructs subjectivity, provoking a selfescape (Scott et al. 2019). The understanding of escape as achieved from a CCT analysis is thus important to our understanding of marketing/consumer research in today's times. It paves the way for the marketing of painful experiences as the new frontier of experiential marketing.

\section{Consumer experiences}

The notion of experience entered the field of consumption and marketing with Holbrook and Hirschman's pioneering article 
in 1982. Four decades later, this notion has become a key element in understanding consumer behavior (Roux and Belk 2019; Tumbat and Belk 2011), and, above all, a foundation for contemporary marketing (Becker and Jaakkola 2020; Lemon and Verhoef 2016). Two distinct research traditions that study consumer experience have been developed while emphasizing the corporate versus consumer perspective (Chaney et al. 2018): consumer experience as a response to managerial stimuli and consumer experience as a subjective consumption process. CCT researchers have been leaders in developing the second research tradition: "CCT research is fundamentally concerned with the cultural meanings, sociohistoric influences, and social dynamics that shape consumer experiences and identities in the myriad messy contexts of everyday life" (Arnould and Thompson 2005, p. 875).

CCT researchers have thus tried to rebalance a functional and utilitarian vision of consumption by applying a so-called cultural perspective that focuses on meaning and individual subjectivity. Heir to a tradition that is both microeconomic and psychological (whether behaviorist or cognitivist) in nature, the customary utilitarian vision of consumption highlights the search for information and the multi-attribute processing of mechanisms of influence - the aim being to optimize transactions undertaken by isolated individuals. Inversely, viewed through a cultural perspective, consumers are less interested in maximizing their benefits and more focused on hedonistic gratification within a given social context (Carù and Cova 2007). Consumption here provokes emotions and feelings that do much more than merely respond to an individual's own desires, because they also touch on the consumer's search for an identity at both individual and collective levels (Arnould and Thompson 2005).

CCT research has investigated a broad array of experiences ranging from mundane ordinary experiences to memorable extraordinary experiences (Carù and Cova 2003). Examples of ordinary experiences abound in CCT literature: from do-ityourself experiences (Moisio et al. 2013) to fashion experiences (Kravets and Sandikci 2014). However, extraordinary experiences, with their transformative effects, have attracted the most attention in the scientific community as proven by the high number of citations for articles that have investigated them (see, for example, Arnould and Price 1993 and Kozinets 2002). Arnould and Price (1993) have notably shown in their pioneering article on extraordinary experiences that a sporting activity such as river rafting provides absorption and integration, personal control, joy and valuing, a spontaneous lettingbe of the process, and a newness of perception. Such an activity involves consumers in an unforgettable process, transforming themselves through experiences in which they are immersed.

Since the seminal works investigating river rafting (Arnould and Price 1993), the Mountain Man rendezvous (Belk and Costa 1998), and skydiving (Celsi et al. 1993) to the more recent works dealing with Everest climbing (Tumbat and Belk 2011), surfing (Canniford and Shankar 2013), roller derby (Thompson and Üstüner 2015), and free skiing and paintballing (Woermann and Rokka 2015), and including works dealing with more culturally oriented experiences such as the Burning Man festival (Kozinets 2002), CCT researchers have framed extraordinary consumption experiences as escapes from the everyday (Holbrook and Hirschman 1982). Overall, the dominant image that emerges of consumers from this rich body of work is that they long for greater harmony with nature, beyond the restricting confines of modernity, searching for magical experiences that supersede individuality with transcendental qualities of the liminal (Turner 1969). Immersion in these extreme experiences enables consumers to feel a sense of community and escape from daily routines.

\section{Consumer experiences as escapes}

Tumbat and Belk (2011, p. 46) argue, in their critical analysis of former literature contributions, that "most studies of various forms of extraordinary consumption experiences within the CCT tradition are framed as in opposition to or an escape from structure." Indeed, the analytical dichotomy between structure and anti-structure proposed by Turner for the ritual process (1969) has had a great impact on the conceptualization of consumption experiences as escapes (Cova et al. 2018; Husemann et al. 2016). Turner (1969) conceptualizes antistructure as potentially regenerative. He theorizes liminality and its anti-structural qualities through the study of preindustrial societies and the ritual processes within them. He particularly explores the theoretical significance of pilgrimages, because they are ideal examples of sacred anti-structure. According to Turner, pilgrimages liberate individuals from the binding constraints of social roles and statuses. Instead, pilgrimages facilitate the experience of "communitas," that is, the feeling of community and belongingness. Turner's theoretical framework appears congruent with CCT research on consumer experiences. For instance, Kozinets (2002, p. 36) describes the Burning Man festival as a "release attempt": "As Turner pointed out in describing the power of anti-structure, a sense of release from these tyrannies-whether imagined or not-is enough to liberate considerable creativity, to release repression, to fulfill some sense of people's hidden potential, to evoke self-expression, and to unleash the potential for selftransformation."

In much of this scholarship on consumption experiences, consumers are depicted as escaping into something that lies on one side of the dichotomies that play out around the following elements of anti-structure (Tumbat and Belk 2011):

- Social interactions among participants are positive and collaborative as opposed to limited. 
- Personal boundaries are attenuated instead of accentuated.

- Goals are common and shared as opposed to singular and individual.

- Experience is sacred and transcends the market as opposed to profane and commercial in nature.

- Participants act within a community without a heightened sense of individuality.

However, Husemann et al. (2016) have demonstrated that structure and anti-structure often coexist in extraordinary experiences, and this is achieved in two different ways: complementary and conflicting. Whereas the complementary way is unproblematic, the conflicting way gives rise to a field of tensions they have identified as "anastructure." For example, in the case of pilgrimages (Husemann et al. 2016), the anastructure is at play when what the individual pilgrim desires in terms of accommodation conflicts with the well-being of the group at the same place.

From sexual fantasies to holidays, escape themes are multiple and different (Cohen and Taylor 1976). The longing for a primitive, sacred nature has been documented in multiple previous studies that analyzed marketed extraordinary experiences (Arnould and Price 1993; Belk and Costa 1998; Canniford and Shankar 2013). Whether it is the sublime beauty of the ocean that goes "beyond the reach of urban culture" in surfing (Canniford and Shankar 2013, p. 1056), the escape into anti-market enclaves (Belk and Costa 1998; Kozinets 2002), or rural walking as escape (Edensor 2000), past research depicts extraordinary experiences as taking place in natural spaces and borderlands that offer consumers some respite from everyday constraints and market logics. More artificial escapist themes have also been contemplated by consumer researchers. Escapes into spectacular built environments such as ESPN Zone, Nike Town, American Girl, and so on (Diamond et al. 2009; Kozinets et al. 2004; Peñaloza 1998) form a rich stream of literature just as all the escapes into ephemeral contexts such as celebrations, festivals, subcultural gatherings, and extreme leisure activities do (see Table 1). These thematic categories are not totally independent and some of them can even be combined in the same form of escape.

A recurrent theme in all these works is the difficulty in living in present-day society. As advanced by Gergen (1991), people overloaded with the nagging anxieties of their saturated selves are seeking to escape this entrapment. Edensor (2000, p. 87) notes, for example, that rural walking has to be understood "as an escape from the 'inauthentic' enactions of everyday urban life, moulded by 'over-civilized' norms of behaviour." Moreover, the topic of escape is far from being just a recurrent research theme. Novels and fictions reflect on - and even shape - the search to be out of view and the will to disappear by contemporary individuals
Table 1 Major themes of escape according to CCT literature (Adapted from Cova et al. 2018)

\begin{tabular}{|c|c|c|}
\hline Theme & Searching for & Contexts and Sources \\
\hline $\begin{array}{l}\text { Nature and } \\
\text { wilderness }\end{array}$ & $\begin{array}{l}\text { Purity, immersion into the } \\
\text { wild, communion with } \\
\text { natural elements }\end{array}$ & $\begin{array}{l}\text { River rafting (Arnould and } \\
\text { Price 1993); gathering at } \\
\text { Mountain Man (Belk and } \\
\text { Costa 1998); surfing } \\
\text { ocean waves (Canniford } \\
\text { and Shankar 2013); } \\
\text { walking in the country- } \\
\text { side (Edensor 2000) }\end{array}$ \\
\hline $\begin{array}{l}\text { Spectacular } \\
\quad \text { built } \\
\text { environm- } \\
\text { ents }\end{array}$ & $\begin{array}{l}\text { Pleasure, entertainment, } \\
\text { fantasies, emotions, } \\
\text { hyper-reality }\end{array}$ & $\begin{array}{l}\text { ESPN Zone (Kozinets et al. } \\
\text { 2004); Nike Town } \\
\text { (Peñaloza 1998); } \\
\text { American Girl (Diamond } \\
\text { et al. 2009) }\end{array}$ \\
\hline $\begin{array}{l}\text { Celebrations } \\
\text { and } \\
\text { festivals }\end{array}$ & $\begin{array}{l}\text { Play and pleasure, rituality } \\
\text { of calendrical events, } \\
\text { breaking social } \\
\text { convention }\end{array}$ & $\begin{array}{l}\text { Burning Man (Kozinets } \\
\text { 2002); rock music festi- } \\
\text { vals (Chaney and } \\
\text { Goulding 2016); Mardi } \\
\text { Gras (Weinberger and } \\
\text { Wallendorf 2012) }\end{array}$ \\
\hline $\begin{array}{l}\text { Subcultural } \\
\text { gatherings }\end{array}$ & $\begin{array}{l}\text { Utopia, community, shift } \\
\text { from one identity to } \\
\text { another, physical } \\
\text { transformation }\end{array}$ & $\begin{array}{l}\text { Star Trek conventions } \\
\text { (Kozinets 2001); biker } \\
\text { rides (Schouten and } \\
\text { McAlexander 1995) }\end{array}$ \\
\hline $\begin{array}{l}\text { Extreme } \\
\quad \text { leisure } \\
\text { activities }\end{array}$ & $\begin{array}{l}\text { High-risk leisure, } \\
\text { challenge, risk, pleasure, } \\
\text { difficult practices, } \\
\text { painful activities }\end{array}$ & $\begin{array}{l}\text { Skydiving (Celsi et al. } \\
\text { 1993); Everest climbing } \\
\text { (Tumbat and Belk 2011); } \\
\text { obstacle racing (Scott } \\
\text { et al. 2017) }\end{array}$ \\
\hline
\end{tabular}

(Heilman 1975). Thus, it seems logical that the analysis of a popular novel could reveal insights about escape in today's context.

\section{A fictional perspective on escape}

CCT tradition argues that a literary analysis of texts should be able to tell us something about cultural phenomenon and that important marketing insight can be derived from works of literature. Indeed, for CCT scholars (Brown 1998, p. 239), "fiction, in actual fact, is truer than truth because, unlike Truth, it does not pretend to be true." In addition, CCT scholars argue the value of reading literature to stimulate discussion in the realm of consumption and marketing theories because both are deeply associated with literature (Brown 2015). In this wake, CCT scholars have studied fiction novels, but also comic books, advertisements, films, and television, to provide insights into theory (Canavan 2018). To contribute to theory, the text to be analyzed must be one of exceptional cultural importance as evidenced by the reception it has received. In addition, it has to be related to consumption. 
To fulfill this requirement, we have chosen to analyze a novel (Ervin 2015) that has been coined by the New York Times ${ }^{1}$ as " a fine meditation on George Orwell's Nineteen Eighty-Four ... the greatest novel in the history of the English language." Indeed, using Orwell's masterpiece as a launching point in our times produces a reflection on the role of consumption and marketing in today's world. The protagonist Ray is a marketer acting on consumption through the ad campaigns he creates and, at the same time, is a typical case of a saturated self whose urban life hinges on consumption. In addition, the whole novel is about escaping from this world:

\begin{abstract}
In this debut novel, Andrew Ervin works familiar ground: the burnt-out protagonist who gives up a comfortable but spiritually toxic life in order to refresh his soul and seek redemption in a far-off-or, in current parlance, "off the grid"-place, which according to the formula will inevitably be populated by locals. The off-the-grid locale is the Isle of Jura in Scotland. The burnt-out case is 33-year-old Ray Welter, an advertising guy in Chicago sorely in need of a change of soul. His marriage is a wreck, his father has died grimly, and Ray is stricken with remorse... for having pulled off a hugely successful - and oh so devious-guerrilla ad campaign to persuade Americans to buy gas-gulping monster S.U.V.s. ${ }^{2}$
\end{abstract}

We expect the analysis of such a text to give us hints that go beyond the notion of anti-structure to comprehend the search for escape in today's world. That will enable our understanding of what escaping means in a post-Orwellian world.

\section{Escaping a post-Orwellian world}

In the novel, Ray is a clever advertising executive who learns how to use social media to manipulate his cause. He makes money but he has lost his way. He has no energy; he does not believe in his career. Overall, Ray thinks that today's world is a big fake and that is so because of marketing, which has transformed authenticity into a commodity:

Ray was supposed to meet Bud at McCrotchety's, the flagship of what would soon become a national chain of theme bars offering sanitized and smoke-free nostalgia. It was meant to resemble an old-fashioned Chicago dayload dive bar, but the traditional urine-and-burntpeanut stink was missing, as were any real old-timer drunks, who were forced to huddle in the few real dives

\footnotetext{
${ }^{1}$ https:/www.nytimes.com/2015/05/31/books/review/burning-down-georgeorwells-house-by-andrew-ervin.html

2 Ibid.
}

that remained. McCrotchety's harkened back to an era brought to a close by bars like McCrotchety's. (Ervin 2015, p. 89)

Just as highlighted by previous CCT work, Rays tries to "escape from the rationality, rules, and stresses of everyday life" (Tumbat and Belk 2011, p. 44). Above all, as a successful marketer, he wants to escape the over-marketization of daily life (Kozinets 2002). Escape is often associated with the notion of alienation (Kozinets 2001), which is understood in the broad sense of the term as an individual condition reflecting disconnect from other people, institutions, or one's natural state of being. Marketing is considered to be a vector of alienation through the commodification of authenticity that casts a shadow on product offers' genuineness (Boltanski and Chiapello 2005). Commodification is tantamount to camouflage isolating an item and reproducing one or several aspects that companies may wish to highlight - thereby converting the item into a nothing more than a model lacking in any real life force, just as McCrotchety's bar. Ray's feeling of alienation is then connected to his role of consumer in a hyperconnected world that he considers as fitting as Orwell's intuition:

It was uncanny. His invention of Big Brother had come to fruition in the form of a vast network of conjoined consumers and Ray now understood that he was one of them. (Ervin 2015, p. 60)

Ray believes that Orwell foresaw everything and then some: Big Brother government, the internet, and so on. On top of that, he feels that our civilization was heading to disintegration:

Things were even worse than what was described in Nineteen Eighty-Four. Not even Orwell could have even predicted the absolute disintegration of privacy. Or the emergence of social media as a means of control. Instead of telescreens, we had smartphones. (Ervin 2015, p. 179)

Ray decides he wants to go to the remote Isle of Jura in Scotland. He thus decamps to the isolated place in order to spend a few months in the cottage where George Orwell wrote most of his seminal novel, Nineteen Eighty-Four. Why Jura? Ray is certain that Jura is far off the grid and that by renting Barnhill, Orwell's old cottage, he's traveling to the ground zero of the novel, going back in time to the place where the future was invented. Ray is thus moved by the same romantic notions (Campbell 1987) that are at the roots of the consumer search for extraordinary experiences and anti-structural contexts. Many of us have held the "cottage by the sea" dream aloft in our imagination, thinking it, at times, to be the ideal 
solution for when life gets messy or our decisions turn out to be disasters.

"I came here with all kinds of romantic notions of communing with nature or whatever, and for a while I felt like I was getting close, but it ultimately hasn't really worked out." (Ervin 2015, p. 215)

Of course, it's a romantic fallacy that changing the scenery changes everything. One of the residents of Jura tells Ray:

"Your problem is, and I hope that you don't mind me
saying so, is that our little isle is just as much a part of
the world as London or Paris or your Chicago, maybe
more so because... although we may be remote, and
that's by choice. . . God bless us, we still like being
connected on our own terms." (Ervin 2015, p. 192)

So much for going off the grid. Ray isn't a very lovable man, but everyone can identify with his need to get away from everything and try to clear his mind someplace he believes to be completely isolated. Unfortunately, no such place exists in the world anymore. Everywhere you go, there you are-you take yourself and all of your baggage with you - and your romantic dream to immerse in an unchanged environment faces the globalization of climate that affects everything everywhere, even the whisky of Isle of Jura:

\section{"When I say that malt whisky is the lifeblood of this little island, I want you to understand that literally, " a resi- dent of Jura said. "This new RAF flight plan changes the amount of the jet fuel in our atmosphere, and our atmosphere is not only what we breathe, but what the whisky breathes." (Ervin 2015, p. 221)}

On top of that, there are other human beings there, too. These others have their own agendas, madnesses, personality problems, and a past.

"Everyone says that the Highlands hospitality makes their residents the warmest and most generous people in the world, but what happens if I get there and there's just as much bullshit as everywhere else? Then there would be no place left I could dream of escaping to." (Ervin 2015, p. 192)

Ray has come to Jura in order to escape a post-Orwellian world, but that is impossible. The kind of anti-structure he is seeking does not exist on the surface of Earth anymore, and he has to accept this state of fact:

Ray chose acceptance: there would be no more fighting it. No more challenging the collective wisdom of his grand and enlightened civilization. He would neither fight any longer nor flee. Not to the most distant corner of the most remote island on the planet or into the darkest recesses of his own miserable and troubled mind. (Ervin 2015, p. 250)

This book is thus the classic story of a man who becomes disillusioned with society, goes off to find himself, and discovers he can't escape himself. However, something happens one night while he is ready to come back to Chicago. Ray is shot at by an old resident of Jura because of the relations he entertains with his daughter. He experiences the sensation of extreme pain before vanishing:

The pain arrived as a new sensation. It wasn't like anything... It fucking hurt... The pain was mesmerizing. (Ervin 2015, p. 248)

Pain eventually becomes worse when one of the residents [Fuller] rescues him:

He watched Fuller tap a barrel of whisky and rub some of it on the wound in his side. That pain was even worse than the initial shotgun. (Ervin 2015, p. 250)

The intense pain that Ray feels is at the same time enthralling and self-destroying. Pain expunges the other-directed part of ourselves. What is left is a state of dissociation from the world and others, with a self that retreats inward into the pain felt in the flesh. The pain Ray feels during this intense embodied experience brings his body to heightened awareness (AllenCollinson and Owton 2015), at the same time it creates a kind of vacuum in Ray's mind, which comes as a release for him. The insight that individuals can lose themselves in an activity has already been acknowledged in past psychological research. However, this research concerned mainly borderline practices such as binge drinking, binge eating, or binge watching media. For instance, Griffin and her colleagues (Griffin et al. 2009) have shown that binge drinking is a way to annihilate the self, with young men voluntarily getting drunk to the point of passing out. What is different with Ray is that he discovers by chance that pain can annihilate his self with some kind of long-term effects.

After being shot, "something was different. It seemed too convenient to attribute the change to his near-death experience" (Ervin 2015, p. 257). Indeed, Ray states that "it's funny how an attempted homicide can make you rethink your life" (p. 257), ascribing thus a transformative effect to the scary and painful shotgun episode he lived through in the Highlands. He comes home a changed man and opens a laundry service. One of his office mates finally finds him and asks, "The fuck happened to you over there?" Ray answers, "Among other things, I got shot" (p. 269). Pain has been 
ephemeral for Ray but its impact on self-transformation has been enduring. After such a shock, he remodels his life.

\section{Pain as erasure of the self: the next level of escape}

The analysis of Ervin's 2015 fiction opens up a new way of comprehending consumer escape in contemporary society that, in the wake of the novel, can be labelled postOrwellian. Indeed, we would argue that today's extraordinary experiences are often about escaping the self rather than just being away. Escape from reflexivity already seems to color the consumer experience. Beyond the appeal of anti-structure, consumers experience what Le Breton (2015) has called "whitening" (in reference to the void evoked by the color white), meaning a greater or lesser absence from oneself, stepping out of one's skin in some way or the other, because it has become so difficult and frustrating to be oneself. In that context, pain appears as a shortcut to whitening. However, although the pain inflicted on Ray was not something he desired, more and more Western individuals search to self-inflict painful experiences such as found in extreme sports (Le Breton 2004). In some cases, they want potentially painful experiences, whether it's the freezing cold temperatures of cryotherapy or the feeling of intense muscle exhaustion from pushing your body to its limits while running a race. ${ }^{3}$

Western individuals increasingly describe feeling exhausted, depressed, or overwhelmed by the quantum of activities they are expected to carry out. Young people feel it in their increasingly vulnerable sense of existence, older individuals feel it when they can no longer look after themselves, and indeed everyone feels it when seeking alternative paths in order to reinvent themselves or simply because they want a break (Le Breton 2015). What all of these categories of emotions have in common is people's desire to lighten their load. After all, everyone aspires on occasion to a bit of down time and freedom from the constraints associated with their identity. Whitening affects all men and women who have come to the end of their rope in terms of performing the personality that society has assigned to them, and to everyone who suffers increasingly from all the family or professional responsibilities that people are expected to assume nowadays, the performances they are supposed to provide, the successes they are asked to achieve, and the exhibitions they are supposed to deliver on social media. Whitening means taking a back seat and refusing demands for greater individualization. It means being at least minimally aware of the possibility of "kicking back" to circumvent the excesses of modern living.

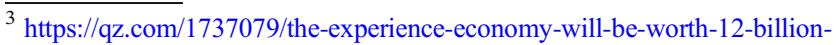
by-2023/
Pain is a major way to achieve whitening and self-escape. Although self-inflicted pain has been exclusively described in modern times as a form of psychopathology (Adler and Adler 2007), it is becoming customary practice for an increasing numbers of Westerners who are moving from the will to be saved from pain to the will to be saved through pain (Shilling and Mellor 2010). Western history is full of spiritual experiences involving self-inflicted pain through forms of self-mutilation, prolonged dancing, flagellation, barefoot pilgrimages, piercing the body, wearing a hair shirt, and so on (Bourke 2014). Bodily pain presented itself to religious individuals and sacred traditions as a means to purify the soul. Pain was believed to serve as atonement for sin (Glucklich 2001). Today, pain is conceived as a self-shattering episode that disrupts the ego's coherence and dissolves its boundaries (Saketopoulou 2014). As such, it provokes a break with the "weariness of the self" (Ehrenberg 2009), that is, the fatigue brought about by the suffocating social expectations of having to constantly construct and re-present one's self. Pain serves to whiten the self.

Although pain is a central facet of the human condition, it "remains understudied and under-theorized within the social sciences" (Green 2011, p. 378), especially in consumer research and marketing. When dealing with pain, marketing research focuses more on trying to remove pain from consumer experience (Lemon and Verhoef 2016) than on inflicting pain on the consumer. CCT scholars have investigated the recent appeal of intense physical and self-inflicted painful experiences (see the next section). This new breed of experience pushes the body to its limits and enables people to willingly face high levels of pain. Contrary to what Ray lived through by being shot, these painful experiences are self-inflicted, which means consumers choose freely to go through them and to pay for them. However, these experiences are not the consequence of deviant behavior such as self-injury (Adler and Adler 2007). Tattooing, piercing, fighting, and obstacle racing appear to depart from the dominant aversion to pain and its avoidance (Shilling and Mellor 2010) toward a tendency to search for escaping oneself through experiencing pain.

\section{Marketed painful experiences}

In the wake of Arnould and Price (1993), a group of CCT researchers has particularly investigated marketed extraordinary experiences. Their contribution has provided a solid background to understand the escape mechanism through the use of the structural/anti-structural dichotomy introduced by Victor Turner (1969). In line with Scott et al.'s (2019) insightful chapter in the Handbook of Research on Identity Theory in Marketing, we contend, however, that several of the CCT works published since 2010 have to be revisited, using the lens of self-escape and thus going beyond the 
Turnerian dichotomy, to fully account for consumers' escapes in extraordinary experiences. In a bid to improve the understanding of contemporary consumer experiences (Becker and Jaakkola 2020), we revisit recent works dealing with three types of self-inflicted painful experiences. In most of these works, pain is said to trigger deep introspective processes that enable consumers to better understand who they are and to redefine the limits of their self-concept. We contend, however, that the main effect of pain in extraordinary experiences is the suspension of consumers' ability to think and thus to provide temporary relief from the burdens of being oneself (Ehrenberg 2009).

\section{Pilgrimage experiences}

CCT research on pilgrimages shows how pain provokes "deceleration" (Husemann and Eckhardt 2019) on the ancient Christian route, the Camino de Santiago de Compostela. The increasing success of such pilgrimages is connected to people searching for opportunities to escape from a sped-up pace of life. In addition, the pain that pilgrims suffer on the Camino de Santiago slows them down physically while also affording them more time and space to reflect. Pain causes pilgrims to decelerate and concentrate on themselves, moving from an external to an internal focus. "Pilgrims experience the painful body as alive and talking, facilitating a dialogue between body and mind" (Husemann and Eckhardt 2019, p. 1152).

Walking the Camino is about reflection and gradually moving toward a better self; pilgrims link these activities to the experiences of suffering the physical challenges of the route. Far from suffering being avoided, it is a necessity for pilgrimages. The physical journey and the endless miles walked in varied and often challenging conditions play a key role in the experience, resulting in painful everyday experiences. Aches, pains, and hardships are so important and prevalent that they often form the basis of conversation on the way to Compostela. Pain and physical struggle seem to push the individual into a more visceral or primitive experience.

Whereas blisters and aches are par for the course on the Camino, acute toe pain is a phenomenon that is underinterpreted in recent works:

Acute toe pain subsumed my sense of self and even if this was not my motive for doing the walk, it gave me religious feelings ... Whenever things got tough I couldn't help but see images of martyrs in my head. On the Camino de Santiago, toe pain plunged me into a world of sacrifice. (Cova and Cova 2019, p. 577)

As such, acute toe pain does not trigger an introspective process but suspends consumer's self-reflexivity. The Cova and
Cova (2019) findings show that acute corporal pain transforms into a spiritual experience that serves as a way to whiten the self. CCT research on the Camino de Santiago de Compostela experience (Cova and Cova 2019; Husemann and Eckhardt 2019; Husemann et al. 2016) can thus be revisited to understand how pain makes self-escape more palpable on pilgrimages.

\section{Tattooing experiences}

Tattooing is the most analyzed painful practice in consumer research (Patterson and Schroeder 2010; Roux and Belk 2019). Tattooing involves the willful solicitation of pain and forms a major aspect of this kind of experience, which can be considered to be spiritual (Pagliarini 2015). Through the pain of tattooing and the marks left on the skin, abstractions are made tangible and real, shaping identity, memory, and spirituality. The process of tattooing draws amorphous or overwhelming interior elements (thoughts, emotions, and memories) out and materializes them through the infliction of pain. One research informant living in the San Francisco Bay Area states that "I wanted to feel hurt, I wanted to feel sore, I wanted to be able to hear my body say, 'wow this hurts me,' and be able to answer it and say, 'yes, that's legitimate, that's true, that's real" (Pagliarini 2015, p. 197).

Although people who tattoo do not seek the experience primarily for the pain, we contend that the prolonged penetration of the needle and the ensuing blood draw the individual into the immediacy of the real (Patterson and Schroeder 2010). In such situations, self-violence and voluntary pain can be productive rather than destructive by enacting the virtue of self-detachment. Self-sacrifice "evokes 'primal' emotions that go beyond discursive thought" (Pagliarini 2015, p. 199). If ontologically the body is the ultimate place we must live in, "with no escape possible" (Roux and Belk 2019, p. 483), the pain felt during tattooing can contribute to transcending people's spatial entrapment by detaching themselves from themselves.

\section{Obstacle race experiences}

Since 2010, a new genre of race has emerged that is peppered with obstacles requiring feats of strength and dexterity and designed to be an over-the-top experience in which participants emerge covered in mud as if they've survived a battle. CCT research has particularly investigated the successful Tough Mudder, a particularly gruelling adventure challenge involving a series of approximately 25 military-style obstacles overcome in half a day by teams of 8 to 10 people: running through burning hay bales, wading through torrents of mud, slithering through tightly enclosed spaces, plunging seven feet into freezing water, and even crawling through $10,000 \mathrm{~V}$ of 
electric wires (Scott et al. 2017). Through sensory intensification, pain summons attentiveness and brings the body into sharp focus, enabling individuals to rediscover their corporeality and that of their teammates. The ritualization of pain at play during this obstacle race facilitates self-renewal through a regained consciousness of physicality and the opportunity for bodily expression that does not otherwise have an outlet.

However, there is also an element of compulsion associated with pain in the way freezing legs and electrocuted limbs demand attention. When the pain is especially intense, though, for instance, when participants are subjected to electrocution, it knocks them down:

The last obstacle's name, Electro-Shock Therapy evokes the self-shattering and the regenerative qualities of the event. Indeed, Electro-Shock Therapy is named after ECT (electroconvulsive therapy), a treatment designed to obscure painful memories and give mental health patients a new lease on life as a result. (Scott et al. 2017, p. 35)

Just like pilgrimages with acute toe pain or tattooing that requires self-sacrifice, there is more to obstacle racing than self-renewal. Whereas the kind of electrical shock described in the last quote represents something that usually people tend to protect themselves from because it could generate immediate cardiac arrest and severe burns, Tough Mudder participants anticipate and willfully go through the ECT obstacle. It is the peak of the experience: the obstacle with $10,000 \mathrm{~V}$ shaking bodies and causing extreme pain, knocking them down and provoking a total suspension of their reflexivity. After the last bout of electrocution, participants describe feeling dazed and lost. The pain of the Tough Mudder event generates self-erasure because participants "forget everything" and escape the stresses and monotony of daily responsibilities (Scott et al. 2017).

Revisiting CCT contributions on pilgrimage, tattooing, and obstacle racing has enabled us to show that the extreme pain lived during these experiences facilitates self-escape. Our claim is that pain contributes to extraordinary experiences by obliterating the reflexivity of the self. That does not hinder the fact that pain felt during extraordinary experiences can also trigger deep introspective processes that allow consumers to better understand who they are and what are their limits. The multiple effects of pain can be presented in the same marketing as with extraordinary experiences. And the providers of painful experiences could thus market ephemeral agonies that provide at the same time self-escape and total mindfulness.

\section{Marketing painful experiences}

Physical malaise can now be considered to be a market opportunity. As marketed pain facilitates self-escape, it potentially enhances the appeal of extraordinary experiences. Indeed, we would argue that extraordinary experiences are often about escaping the self rather than just temporarily being away. As a consequence, one can state that "pain pays for experience providers" (Brown et al. 2018, p. 60) because consumers pay significant amounts of money for an experience that is explicitly marketed as painful. Who are the consumers ready to pay for pain? Marginal people? Let's have a look at the numbers. According to the Pilgrim's Office in Santiago (https://oficinadelperegrino.com/en/statistics/), in 2019, 347,578 pilgrims received the Compostela certificate attesting to their completion of the pilgrimage (versus only 2491 in 1986). After 10 years of existence Tough Mudder accounts for 5 million participants around the world (https:// toughmudder.com/press-room/). And, finally, it is worth noting that three in ten $(30 \%)$ of Americans have at least one tattoo, (https://www.ipsos.com/en-us/news-polls/moreamericans-have-tattoos-today), even if they do not all experience acute pain during the tattooing process.

Escaping through pain should thus not be conceived as a marginal phenomenon. However, it is not for everyone. Scott et al. (2017) highlight that Tough Mudder is especially attractive to the worn-out knowledge workers who are not only working jobs of limited physicality but also feel the burden of constant self-actualization. Indeed, when marketing the event, Tough Mudder primarily targets white-collar professionals. These consumers fit perfectly the image of the saturated self (Gergen 1991), that is, people who suffer from their professional responsibilities and from their sedentary life. Blue-collar workers, even if eligible in terms of saturation of the self, do not find in these activities an escape from their usual work context.

Finally, escaping through pain does not seem to function in isolation of an anti-structure. The religious context of the Camino de Santiago provides a perfect setting for the acute toe pain to facilitate self-escape. The spiritual quest driving tattooing supports self-sacrifice. The community feeling of the Mudders and their unique sense of camaraderie creates a stage for the whitening phenomenon. That means that the setting has to be extraordinary in a Turnerian sense - an anti-structure - to make self-escape possible. In an ordinary setting, just as in a dentist office, pain generally does not transform itself into a self-escape event if it is extreme.

Marketing had the tendency to instrumentalize and medicalize pain that was seen as almost purely negative. Now, making life difficult for consumers has become an alternative driver of experience marketing. Whereas consumers were supposed to seek pleasure and avoid pain, they now search more and more for painful experiences. They turn to market intermediaries that sell not just another experience but also the suspension of the mind through painful means. Some of the developments in the sport business since the new millennium confirm this trend. CrossFit is a group fitness program that 
incorporates a variety of weightlifting and gymnastic movements performed at high intensities. Since its inception in 2000 , CrossFit has rapidly grown into a billion-dollar international business. The company now operates in more than 15,000 locations worldwide. CrossFit's program is intense and unconventional. A typical CrossFit workout might include rounds of Olympic weightlifting sandwiched between medium-distance sprints or an extremely high volume of repetitions of already challenging exercises strung together (Powers and Greenwell 2017). High levels of pain experienced during these workouts contribute to consumers' selfescape. Although being more a niche market, mixed martial arts (MMA) is also on the rise. MMA experiences feature participants in a ring or a caged-in area, inflicting pain on their opponents, inter alia, by punching, kicking, elbowing, and kneeing their opponents into submission (Green 2011; Spencer 2014).

Building on CCT research since the 2010s, our contribution thus informs marketing theory and practice on the evolution of experiential marketing and experiential consumption. First, extraordinary experiences have to be understood as embodied. Second, they have to be considered in the light of escapism. Embodied experiences of escapism have been investigated in sports, clubbing, and other leisure pursuits (Arnould and Price 1993; Belk and Costa 1998; Canniford and Shankar 2013; Celsi et al. 1993; Kozinets 2002). These investigations could be deepened and extended by considering the consumer suffering that enhances the potential of escapism in each of these experiences. For example, participating in Burning Man (Kozinets 2002) in the blazing, inhospitable desert of Nevada could not be just about community and sacred rituals; it could also be about pain and sacrifice to come and stay there several nights. Thus, our third and major contribution is to reposition pain as a major component of each extraordinary experience and a component that can't be underestimated but needs to be reconsidered.

\section{Conclusions and further research}

Further research should investigate why these painful experiences are appealing particularly to younger generations. Pain has been a constant companion for humanity. However, it has been eliminated or reduced by recent developments in medicine and the production of pain relievers. Members of the younger generationsbaby boomers and those following - have thus suffered from illnesses much less than their predecessors. In addition, for a great number of contemporary Western people, wars and conflicts are alien to their lives since the end of the Second World War. However, anthropologically, pain and violence have been part of the human condition and their absence leads to search for a way to experience them. It seems that today the ultimate type of experience - beyond immersing oneself in an anti-structure - has to do with something forgotten if not rejected: war-type violence. As emphasized by Baricco (2006) in his re-reading of the Iliad, we must recall

something disturbing but inexorably true: for millennia war has been for men the circumstances in which the intensity - the beauty - of life is released in all its power and truth. It was almost the only possibility for changing one's destiny, for discovering the truth of oneself, for gaining a high ethical knowledge. In contrast to the anemic emotions of life and the mediocre moral stature of everyday, war sets the world in motion and thrusts individuals outside their accustomed confines. (Baricco 2006, p. 156).

Indeed, painful experiences go beyond mere anti-structure to provide today's consumers with a glimpse of the atrocious practice of mortal combat that used to be the best experience "that enables one to truly exist" (Baricco 2006, p. 157). This may appear to run counter to what humanity is living while fighting an immaterial and invisible enemy, currently Covid-19. However, the mortal combat against the virus undertaken by medical staff is not without connection to the intensity of war.

\section{References}

Adler, P. A., \& Adler, P. (2007). The demedicalization of self-injury: from psychopathology to sociological deviance. Journal of Contemporary Ethnography, 36(5), 537-570.

Allen-Collinson, J., \& Owton, H. (2015). Intense embodiment: senses of heat in women's running and boxing. Body \& Society, 21(2), 245268.

Arnould, E. J., \& Price, L. L. (1993). River magic: extraordinary experience and the extended service encounter. Journal of Consumer Research, 20(1), 24-45.

Arnould, E. J., \& Thompson, C. J. (2005). Consumer culture theory (CCT): twenty years of research. Journal of Consumer Research, $31(4), 868-882$.

Baricco, A. (2006). An Iliad. New York: Vintage.

Becker, L., \& Jaakkola, E. (2020). Customer experience: fundamental premises and implications for research. Journal of the Academy of Marketing Science, (January), 1-19.

Belk, R. W., \& Costa, J. A. (1998). The mountain man myth: a contemporary consuming fantasy. Journal of Consumer Research, 25(3), $218-240$.

Boltanski, L., \& Chiapello, E. (2005). The new spirit of capitalism. London: Verso.

Bourke, J. (2014). The story of pain: From prayer to painkillers. Oxford: Oxford University Press.

Brown, S. (1998). Postmodern marketing two: Telling tales. London: Thomson.

Brown, S. (2015). Bow to stern: can literary theory plumb an unfathomable brand? Marketing Theory, 15(4), 445-464.

Brown, S., Stevens, L., \& MacLaran, P. (2018). Epic aspects of retail encounters: the Iliad of Hollister. Journal of Retailing, 94(1), 58-72.

Campbell, C. (1987). The romantic ethic and the spirit of modern consumerism. Oxford: Basil Blackwell. 
Canavan, B. (2018). Breakfast, lunch and dinner at Tiffany's: existentialism and consumption in Capote's novella. Marketing Theory, 18(4), 571-578.

Canniford, R., \& Shankar, A. (2013). Purifying practices: how consumers assemble romantic experiences of nature. Journal of Consumer Research, 39(5), 1051-1069.

Carù, A., \& Cova, B. (2003). Revisiting consumption experience: a more humble but complete view of the concept. Marketing Theory, 3(2), 267-286.

Carù, A., \& Cova, B. (Eds.). (2007). Consuming experience. London: Routledge.

Celsi, R. L., Rose, R. L., \& Leigh, T. W. (1993). An exploration of highrisk leisure consumption through skydiving. Journal of Consumer Research, 20(1), 1-23.

Chaney, D., \& Goulding, C. (2016). Dress, transformation, and conformity in the heavy rock subculture. Journal of Business Research, 69(1), 155-165.

Chaney, D., Lunardo, R., \& Mencarelli, R. (2018). Consumption experience: past, present and future. Qualitative Market Research: An International Journal, 21(4), 402-420.

Cohen, S., \& Taylor, L. (1976). Escape attempts: The theory and practice of resistance to everyday life. London: Allen Lane.

Cova, V., \& Cova, B. (2019). Pain, suffering and the consumption of spirituality: a toe story. Journal of Marketing Management, 35(56), 565-585.

Cova, B., Carù, A., \& Cayla, J. (2018). Re-conceptualizing escape in consumer research. Qualitative Market Research: An International Journal, 21(4), 445-464.

Diamond, N., Sherry Jr., J. F., Muñiz Jr., A. M., McGrath, M. A., Kozinets, R. V., \& Borghini, S. (2009). American girl and the brand gestalt: closing the loop on sociocultural branding research. Journal of Marketing, 73(3), 118-134.

Edensor, T. (2000). Walking in the British countryside: reflexivity, embodied practices and ways to escape. Body \& Society, 6(3-4), 81106.

Ehrenberg, A. (2009). The weariness of the self: Diagnosing the history of depression in the contemporary age. Montreal: McGill-Queen's University Press.

Ervin, A. (2015). Burning down George Orwell's house. London: Soho.

Gergen, K. (1991). The saturated self: Dilemmas of identity in contemporary life. New York: Basic Books.

Glucklich, A. (2001). Sacred pain: Hurting the body for the sake of the soul. Oxford: Oxford University Press.

Green, K. (2011). It hurts so it is real: sensing the seduction of mixed martial arts. Social \& Cultural Geography, 12(04), 377-396.

Griffin, C., Bengry-Howell, A., Hackley, C., Mistral, W., \& Szmigin, I. (2009). Every time I do it I absolutely annihilate myself: loss of (self-) consciousness and loss of memory in young people's drinking narratives. Sociology, 43(3), 457-476.

Heilman, R. B. (1975). Escape and escapism varieties of literary experience. The Sewanee Review, 83(3), 439-458.

Holbrook, M. B., \& Hirschman, E. C. (1982). The experiential aspects of consumption: consumer fantasies, feelings, and fun. Journal of Consumer Research, 9(2), 132-140.

Husemann, K. C., \& Eckhardt, G. M. (2019). Consumer deceleration. Journal of Consumer Research, 45(6), 1142-1163.

Husemann, K. C., Eckhardt, G. M., Grohs, R., \& Saceanu, R. E. (2016). The dynamic interplay between structure, anastructure and antistructure in extraordinary experiences. Journal of Business Research, 69(9), 3361-3370.

Kozinets, R. V. (2001). Utopian enterprise: articulating the meanings of Star Trek's culture of consumption. Journal of Consumer Research, 28(1), 67-88.

Kozinets, R. V. (2002). Can consumers escape the market? Emancipatory illuminations from burning man. Journal of Consumer Research, 29(1), 20-38.
Kozinets, R. V., Sherry, J. F., Storm, D., Duhachek, A., Nuttavuthisit, K., \& DeBerry-Spence, B. (2004). Ludic agency and retail spectacle. Journal of Consumer Research, 31(3), 658-672.

Kravets, O., \& Sandikci, O. (2014). Competently ordinary: new middle class consumers in the emerging markets. Journal of Marketing, $78(4), 125-140$.

Le Breton, D. (2004). The anthropology of adolescent risk-taking behaviours. Body \& Society, 10(1), 1-15.

Le Breton, D. (2015). Disparaître de soi: Une tentation contemporaine. Paris: Métailié.

Lemon, K. N., \& Verhoef, P. C. (2016). Understanding customer experience throughout the customer journey. Journal of Marketing, 80(6), 69-96.

Moisio, R., Arnould, E. J., \& Gentry, J. W. (2013). Productive consumption in the class-mediated construction of domestic masculinity: doit-yourself (DIY) home improvement in men's identity work. Journal of Consumer Research, 40(2), 298-316.

Pagliarini, M. A. (2015). Spiritual tattooing: pain, materialization, and transformation. Journal of Religion and Violence, 3(2), 189-212.

Patterson, M., \& Schroeder, J. (2010). Borderlines: skin, tattoos and consumer culture theory. Marketing Theory, 10(3), 253-267.

Peñaloza, L. (1998). Just doing it: a visual ethnographic study of spectacular consumption behavior at Nike Town. Consumption, Markets and Culture, 2(4), 337-400.

Powers, D., \& Greenwell, D. M. (2017). Branded fitness: exercise and promotional culture. Journal of Consumer Culture, 17(3), 523-541.

Roux, D., \& Belk, R. (2019). The body as (another) place: producing embodied heterotopias through tattooing. Journal of Consumer Research, 46(3), 483-507.

Saketopoulou, A. (2014). To suffer pleasure: the shattering of the ego as the psychic labor of perverse sexuality. Studies in Gender and Sexuality, 15(4), 254-268.

Schouten, J. W., \& McAlexander, J. H. (1995). Subcultures of consumption: an ethnography of the new bikers. Journal of Consumer Research, 22(1), 43-61.

Scott, R., Cayla, J., \& Cova, B. (2017). Selling pain to the saturated self. Journal of Consumer Research, 44(1), 22-43.

Scott, R., Husemann, K. C., \& Hill, T. (2019). Identity verification through pain in extraordinary consumer experiences. In A. Reed II \& M. Forehand (Eds.), Handbook of research on identity theory in marketing (pp. 255-269). Cheltenham: Edward Elgar.

Shilling, C., \& Mellor, P. A. (2010). Saved from pain or saved through pain? Modernity, instrumentalization and the religious use of pain as a body technique. European Journal of Social Theory, 13(4), 521537.

Spencer, D. C. (2014). Sensing violence: an ethnography of mixed martial arts. Ethnography, 15(2), 232-254.

Thompson, C. J., \& Üstüner, T. (2015). Women skating on the edge: marketplace performances as ideological edgework. Journal of Consumer Research, 42(2), 235-265.

Tumbat, G., \& Belk, R. W. (2011). Marketplace tensions in extraordinary experiences. Journal of Consumer Research, 38(1), 42-61.

Turner, V. W. (1969). The ritual process: Structure and anti-structure. Chicago: Aldine.

Weinberger, M. F., \& Wallendorf, M. (2012). Intracommunity gifting at the intersection of contemporary moral and market economies. Journal of Consumer Research, 39(1), 74-92.

Woermann, N., \& Rokka, J. (2015). Timeflow: how consumption practices shape consumers' temporal experiences. Journal of Consumer Research, 41(6), 1486-1508.

Publisher's note Springer Nature remains neutral with regard to jurisdictional claims in published maps and institutional affiliations. 